\title{
PENGARUH BEBAN KERJA DAN KESELAMATAN KERJA TERHADAP PRODUKTIVITAS KERJA PADA PEGAWAI PELABUHAN PERIKANAN NUSANTARA KARANGANTU DIKOTA SERANG
}

\author{
Ahmad Saputra'),Mirza Abdy Khairusy ${ }^{2)}$ \\ mirza@unbaja.ac.id
}

\begin{abstract}
ABSTRAK
Penelitian ini bertujuan untuk mengetahui Pengaruh Beban Kerja dan Keselamatan Kerja Terhadap Produktivitas Kerja Pada Pegawai Pelabuhan Perikanan Nusantara Karangantu Serang Banten. Latar belakang penelitian ini berkaitan dengan kurangnya perhatian kepada sumber daya manusia, beban kerja yang belum sesuai dengan tanggung jawab pekerjaan dan keselamatan yang masih tergolong rendah yang mana belum terfokus pada keselamatan dalam memberikan pemahaman untuk meningkatkan produktivitas kerja.

Populasi penelitian adalah semua pegawai Pelabuhan Perikanan Nusantara Karangantu sebanyak 60 orang dengan seluruh populasi akan dijadikan sampel sebanyak 60 responden. Metode yang digunakan dalam penelitian ini adalah metode Assosiatif Kasual dengan pendekatan Kuantitatif. Teknik analisis data yang digunakan adalah analisis regresi linier berganda.

Hasil penelitian menunjukkan bahwa beban kerja dan keselamatan kerja memberikan pengaruh sebesar $49,1 \%$ terhadap produktivitas kerja, angka 49,1\% disini artinya setiap perubahan produktivitas kerja sebesar $49,1 \%$ dipengaruhi oleh perubahan variabel beban kerja dan keselamatan kerja. Adapun sisanya sebesar 50,9\% disebabkan oleh variabel - variabel lain diluar kedua variabel tersebut yang tidak dilibatkan dalam penelitian ini, antara lain kepemimpinan, kondisi kerja.
\end{abstract}

Kata Kunci : Beban Kerja , Keselamatan Kerja dan Produktivitas Kerja 


\section{ABSTRACT}

This study aims to determine the Effect of Workload and Work Safety on Work Productivity in the Karangantu Serang Banten archipelago Fisheries Port Employees. The background of this research relates to the lack of attention to human resources, workload that is not in accordance with work responsibilities and safety that is still relatively low which has not been focused on work safety on providing understanding to improve work productivity.

The study population is all employees of the Karangantu Archipelago Fisheries Port as many as 60 people with the entire population will be sampled as many as 60 respondents. The method used in this study is the Casual Associative method with a quantitative approach. The data analysis technique used is multiple linear regression analysis.

The results showed that workload and work safety had an effect of $49.1 \%$ on work productivity, a figure of $49.1 \%$ here means that any change in work productivity by $49.1 \%$ was influenced by changes in workload and work safety variables. The remaining $50.9 \%$ is caused by other variables beyond the two variables not included in this study, including leadership, working conditions.

Keywords: Workload, Work Safety a nd Work Productivity

\section{PENDAHULUAN}

\subsection{LatarBelakangMasalah}

Indonesia sebagai salah satu wilayah maritim yang memiliki wilayah lebih luas dari wilayah daratan. Indonesia yang memiliki berbagai pulau baik dari pulau kecil dan pulau besar yang tersebar luas dari sabang sampai merouke.Indonesia tentunya memiliki sebuah kajian yang cukup luas dan mendalam tentang kelautan yang mereka kelola sehingga potensi - potensi yang ada di laut dapat terungkap dan dipecahkan .

Setiap pelabuhan memiliki berbagai macam bagian penting untuk menunjang berlangsungnya kegiatan pelabuhan dan membantu dalam mencapainya tujuan dan target tertentu. Salah satu dari bagian terpenting tersebut ialah pelabuhan perikanan yang menjadikan dasar akses - akses pelabuhan perikanan dari berstara kecil hingga besar, pelabuhan perikanan adalah salah satu sumber pencarian yang dilakukan sebagian masyarakat yang menjadikan fungsi sebagai pencari ikan. Namun dalam hal itu kita juga mempunyai komponen yang harus diperhatikan dari sebuah pelabuhan yang menjadikan sebuah pegawai yang baik dalam menunjang suatu kebelangsungan pekerjaan para pencari ikan dan mitra-mitra pelabuhan. Pegawai atau sumber daya manusia adalah komponen 
JUMANIS - BAJA VOL 4 NO 1 Prodi Kewirausahaan Februari 2022

ISSN : 2686-0554

ESSN : 2686-5939

DOI : 10.47080

terpenting pada suatu pelabuhan perikanan. Pekerjaan yang menjadikan suatu tanggung jawab kepada pelayanan - pelayanan kepada masyarakat dan mitra - mitra pelabuhan akan menjadikan suatu tingkatan yang harus diperhatikan oleh pelabuhan, salah satu yang harus diperhatikan adalah bagaimana pegawai menjalankan perkerjaannya dari segi tanggung jawab, waktu, kebutuhan pegawai, dan rasa emosionalnya. Sehingga dengan adanya hal seperti itu pelabuhan dapatmengetahui pekerjaan pegawainya dan sebagai pelabuhan/instansi dapat bisa memberikan perbaikan pekerjaan dengan adanya pengembangan pengembangan yang meliputi pelatihan, pendidikan, konseling kerja. Bagaimanapun pegawai yang dalam sebuah pelabuhan perikanan, pelabuhan yang melayani masyarakat sekitar baik yang berfungsi sebagai nelayan maupun penjual/pengepul dan pada akhirnya pelabuhan perikananlah faktor utama pendukung terwujudnya tujuan didalam suatu kebijakan-kebijakan peraturan dan tempat administrasi bagi kehidupan para masyarakat khususnya nelayan.

Pada hakekatnya pandangan hidup dan sikap mental dapat juga menjadi pendorong untuk tidak cepat merasa puas akan tetapi dapat mampu mengembangkan diri dalam meningkatkan kinerjanya, pengertian produktivtas kerja menurut Hasibuan (2014:128) merupakan "perbandingan antara keluaran dan masukan serta mengutarakan cara pemanfaatan baik terhadap sumber - sumber dalam memproduksi suatu barang dan jasa”. Dari teori diatas dapat dikatakan bahwa produktivitas menyentuh berbagai aspek didalam diri setiap manusia seperti pandangan hidup, sikap, mental, etika dan keahlian untuk dijadikan pendorong dalam meningkatkan mutu dalam diri setiap harinya agar lebih baik.

Semakin tinggi pegawai mendapatkan tanggung jawab dan tuntunan dari pekerjaan tersebut maka akan semakin tinggi pula pegawai untuk memenuhi tantangan bagi pelabuhan dalam mengelola sumber daya manusia yang berkualitas. Sebuah kenyataan yang tidak dapat disangka bahwa beban kerja dapat menjadi salah satu penghambat dalam pekerjaan pegawai yang semakin tinggi tanggung jawabnya, hal ini mengakibatkan pegawai harus meluangkan waktu diluar jam kerja untuk menyelesaikan pekerjaannya untuk dapat mencapai target pekerjaan dengan tepat waktu. Dengan jam kerja yang telah ditentukan pelabuhan dan kadang menjadikan pekerjaan tidak selesai saat jam kerja, pegawai sering kali bekerja diluar jam kerja untuk menyelesaikan pekerjaannya. Pekerjaan diluar jam kerja mempunyai konsekuensi tersendiri bagi pegawai salah satunya kehilangan waktu untuk beristirahat. Tingginya beban kerja yang ada dalam setiap pegawai pelabuhan membawa 
JUMANIS - BAJA VOL 4 NO 1 Prodi Kewirausahaan Februari 2022

ISSN : 2686-0554

ESSN : 2686-5939

DOI : 10.47080

dampak negatif bagi produktivitas kerja pegawai pada pelabuhan. Menurut (Soleman, 2011) ia mengatakan bahwa "beban kerja adalah besaran pekerjaan yang harus dipikul oleh suatu jabatan atau unit organisasi dan merupakan hasil kali antara volume kerja dan norma waktu”.

Selian Beban kerja, pegawai pun harus dapat mempertimbangkan keselamatan kerjanya yang menjadikan mereka semakin tidak terburu - buru dalam melaksanakan pekerjaannya. Kecerobohan akibat kelengahan baik disengaja maupun tidak sengaja terhadap keselamatan dalam bekerja dapat merugikan tenaga kerja maupun pelabuhan/instansi, berupa kerugian harta benda, cacat dan kematian, kehilangan waktu kerja, telambatnya proses operasional kerja dan kerugian-kerugian lain baik langsung maupun langsung tidak langsun. Sehingga dengan adanya kejadian - kejadian tersebut akan mendapatkan dampak yang tidak baik bagi pegawai dan pelabuhan. Dengan adanya akibat - akibat tersebut maka implementasi Keselamatan dan Kesehatan Kerja (K3) berpengaruh terhadap produktivitas tenaga kerja.

Keselamatan dan kesehatan kerja juga mempunyai banyak pengaruh terhadap faktor kecelakaan, pegawai harus wajib mematuhi standar yang diberikan pelabuhan yaitu K3 agar pegawai tidak terjadi hal-hal yang negatif bagi diri baik pegawai maupun nelayan yang mencari ikan. Keselamatan dan kesehatan dalam setiap pekerjaan perlu diperhatikan disebuah lingkungan kerja, karena kesehatan merupakan dimana suatu kondisi yang bebas dari gangguan fisik, mental, emosi, atau rasa sakit yang disebabkan oleh lingkungan kerja sedangkan keselamatan merupakan suatu dimana kondisi kerja yang aman atau selamat dari suatu penderitaan, kerusakan atau kerugian ditempat kerja. Apabila pegawai dalam keadaan kondisi tubuh yang sehat baik sehat jasmani maupun sehat rohani dan pegawa didukung oleh suatu sarana dan prasarana yang terjamin keselamatannya maka produktivitas kerja akan dapat ditingkatkan.

Berdasarkan yang telah diungkapkan sebelumnya dapat disimpulkan bahwa beban dan keselamatan kerja berkontibusi terhadap produktivitas kerja pegawai, karena lingkungan kerja dapat memberikan pikiran dan fisik baik jasmani dan rohani menjadi perhatian utama dari beban dan keselamatan kerja dapat berpengaruh terhadap hasil kerja manusia. Dengan adanya jaminan atau program dalam menjamin beban dan mencegah angka kecelakaan kerja yang diberikan oleh pelabuhan maka diharapkan pekerjaan dari pegawai dapat berjalan sesuai dengan yang diinginkan oleh pelabuhan. 
JUMANIS - BAJA VOL 4 NO 1 Prodi Kewirausahaan Februari 2022

ISSN : 2686-0554

ESSN : 2686-5939

DOI : 10.47080

Semua alasan tersebut diduga dapat mempengaruhi produktivitas kerja pegaawai. penulis tertarik untuk meneliti beban kerja dan keselamatan kerja terhadap produktivitas kerja pegawai yang ada pada Pelabuhan Perikanan Nusantara Karangantu, maka penulis beniat untuk menulis skripsi yang berjudul " Pengaruh Beban Kerja dan Keselamatan Kerja terhadap Produktivitas kerja Pegawai Pada Pelabuhan Perikanan Nusantara Karangantu “

\section{Landasan Teori}

\subsection{Produktivitas Kerja}

Produktivitas Kerja menurut Tjutju Yuniarsih (2009:156) produktivitas adalah "hasil kongkrit yang dihasilkan oleh individu atau kelompok, selama satuan waktu tertentu dalam suatu proses kerja. Dalam hal ini, semakin tinggi produksi yang dihasilkan dalam waktu yang semakin singkat, maka dikatakan bahwa tingkat produktivitasnya mempunyai nilai yang tinggi, dan begitu pula dengan sebaliknya”.

Menurut Greebeg dalam Muchdarsyah (2014:12) produktivitas sebagai perbandingan antara totalitas pengeluaran pada waktu tertentu dibagi totalitas masukan selama periode tertentu.

Menurut Tjuju Yuniarsih (2013:156) Produktivitas dapat diartikan sebagai hasil konkrit yang dihasilkan oleh individu atau kelompok, selama satuan waktu dalam waktu suatu proses kerja. Produktivitas dapat diartikan sebagai ratio antara hasil nyata (output) dalam bentuk barang dan jasa, dengan masukan (input) yang sebenarnya.

Kemudian menurut Nawawi (2009:157) mengemukakan bahwa produktivitas kerja merupakan perbandingan antara hasil yang diperoleh (output) dengan jumlah sumber daya yang digunakan sebagai masukan (input).

Menurut Sutrisno (2016:84) mengemukakan bahwa Indikator produktivitas kerja antara lain : Kemampuan, meningkatkan hasil yang dicapai, semangat kerja, pengembangan, mutu, efesien.

\subsection{Beban Kerja}

Beban kerja adalah besaran pekerjaan yang harus dipikul suatu jabatan atau unit organisasi dan merupakan hasil antara volume kerja dan norma waktu (Soleman:2011). 
JUMANIS - BAJA VOL 4 NO 1 Prodi Kewirausahaan Februari 2022

ISSN : 2686-0554

ESSN : 2686-5939

DOI : 10.47080

Soleman (2011) mengembangkan beban kerja dalam 2 skala penilaian, yaitu:“(1) Faktor eksternal yang dibagi atas tugas - tugas yang diberikan, kompleksitas pekerjaan, lamanya waktu kerja dan istirahat. (2) Faktor internal yang terbagi atas motivasi, persepsi, kenginan dan kepuasan".

Menurut Apriani (2013) yang dimaksud dengan beban kerja adalah banyaknya tugas dengan tanggung jawab yang harus dilakukan organisasi atau unit - unitnya dalam satuan waktu dan jumlah tenaga kerja tertentu. Hal ini bias disebabkan oleh tingkat keahlian yang dituntut terlalu tinggi. Kecepatan kerja mungkin terlalu tinggi, volume kerja mungkin terlalu banyak dan sebagainya.

Menurut Suci R. Mar'ih Koesmowidjojo (2017), Indikator beban kerja yaitu 1). Kondisi Pekerjaan, 2)Penggunaan Waktu, 3)Target yang harus dicapai.

\subsection{Keselamatan Kerja}

Keselamatan kerja menurut Suma'mur (2009:104), mengatikan bahwa keselamatan kerja adalah rangkaian usaha untuk menciptakan suasana kerja yang aman dan tentram bagi para karywan/pegawai yang bekerja diperusahaan yang bersangkutan.

Menurut Suparyadi (2015) Mengemukakan bahwa kesehatan dan Keselamatan sebagai suatu kondisi dimana pegawai terbebas dari kemungkinan terjadinya kecelakaan.

Menurut Mangkunegara (2016:161) keselamatan kerja adalah kondisi aman atau selamat dari penderitaan, kerusakan atau kerugian di tempat kerja.

Menurut Moenir (2010:203) dalam Afrizal Firmanzah (2017) mengemukakan bahawa indicator keselamatan kerja adalah sebagai berikut :

a. Lingkungan kerja secara fisik

1. Penempatan benda atau barang dilakukan dengan diberi tanda - tanda, batas - batas, dan peringatan yang cukup.

2. Penyediakan perlengkapan yang mampu untuk digunakan sebagai alat pencegahan, pertolongan dan perlindungan.

b. Lingkungan Sosial Psikologis

Jaminan keselamatan kerja secara psikologis dapat dilihat pada aturan - aturan yang mengenai berbagai jaminan pekerjaan yang meliputi :

1. Aturan mengenai ketertiban organisasi dan atau pekerjaan hendaknya diperlakukan secara merata kepada semua pegawai tanpa kecuali. Masalah - masalah seperti itulah 
JUMANIS - BAJA VOL 4 NO 1 Prodi Kewirausahaan Februari 2022

ISSN : 2686-0554

ESSN : 2686-5939

DOI : 10.47080

yang sering menjadi sebab utama kegagalan pegawai termasuk para eksekutif dalam pekerjaan.

2. Perawatan dan pemeliharaan asuransi terhadap para pegawai yang melakukan pekerjaan yang bahaya dan beresiko, yang kemungkinan terjadi kecelakaan kerja yang sangat besar. Asuransi meliputi jenis tingkat penderitaan yang dialami pada kecelakaan. Adanya asuransi jelas menimbulkan ketenangan pegawai dalam bekerja dan menimbulkan ketenangan akan dapat ditingkatkan karenanya.

\subsection{Kerangka Pemikiran}

Berdasarkan kerangka Pemikiran, skema dalam penelitian ini adalah sebagai berikut :

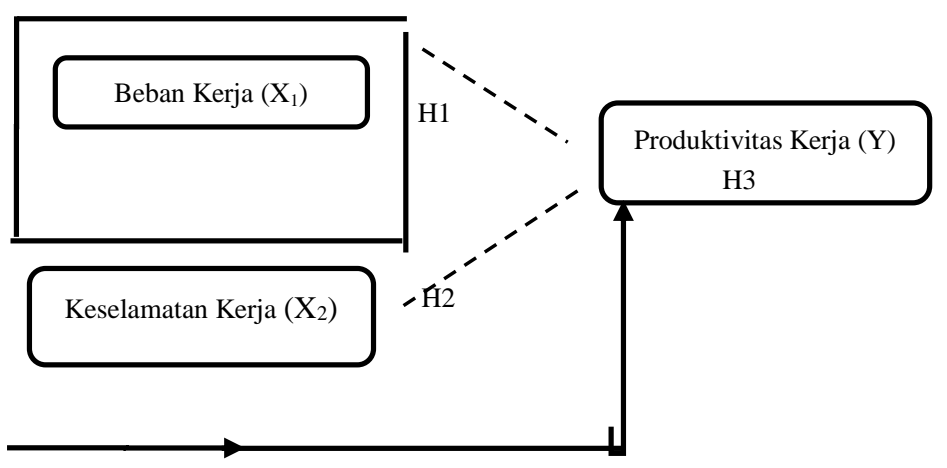

- - - - - - - - : :Pengaruh Secara Parsial

: Pengaruh Secara Simultan

Gambar 2.1 KerangkaPemikiran

\subsection{Hipotesis}

H1 = Terdapat pengaruh Beban Kerja terhadap Produktivitas Kerja Pegawai pada Pelabuhan Perikanan Nusantara KarangAntu

H2 = Terdapat pengaruh Keselamatan Kerja terhadap Produktivitas Kerja Pegawai pada Pelabuhan Perikanan Nusantara KarangAntu

H3 = Terdapat pengaruh Beban Kerja dan Keselamatan Kerja terhadap Produktivitas Kerja Pegawai pada Pelabuhan Perikanan Nusantara KarangAntu 


\section{MetodelogiPenelitian}

\subsection{JenisPenelitian}

Jenis Penelitian ini merupakan penelitian Assosiatif Kasual dengan pendekatan Kuantitatif. Menurut Sugiyono (2018:37) penelitian Assosiatif Kasual adalah penelitian yang bersifat menanyakan hubungan antara dua variable atau lebih. Penelitian ini menjelaskan hubungan mempengaruhi dan dipengaruhi dari variabel - variabel yang akan diteliti. Penelitian ini menganalisis pengaruh beban kerja dan keselamatan kerja terhadap produktivitas kerja pegawai.

\subsection{Populasi dan Sampel}

A. Populasi

Menurut Sugiyono (2018:80) Populasi adalah wilayah generalisasi yang terdiri atas objek atau subjek yang mempunyai kualitas dan karakteristik tertentu untuk ditetapkan oleh peneliti untuk dipelajari dan kemudian ditarik kesimpulannya.

Populasi dalam penelitian ini adalah sejumlah 60 pegawai dan responden akan mengisi kuesioner yang diberikan oleh penulis pada bulanAgustus 2019 yang berlokasi di Pelabuhan Perikanan Nusantara Karangantu Serang Banten.

B. Sampel

Menurut Sugiyono (2018:81) Sampel adalah bagian dari jumlah dan karakter yang dimiliki oleh populasi tersebut.

Dalam Penelitian ini berhubung populasi berjumlah kecil maka peneliti mengambil seluruh anggota populasi untuk dijadikan sampel sebanyak 60 responden.

\subsection{MetodePengambilanSampel}

Metode pengambilan sampelnya menggunakan nonprobability sampling, yaitu teknik pengambilan sampel yang tidak memberi peluang/kesempatan sama bagi setiap unsur atau anggota populasi untuk dipilih menjadi sampel. Teknik sampel nonprobability ini menggunakan sampling jenuh, menurut Sugiyono (2018:85) sampling jenuh adalah teknik penentuan sampel bila semua anggota populasi digunakan menjadi sampel. Teknik pengumpulan data yang dilakukan dalam penelitian ini dengan kuesioner yang berisi jumlah pertanyaan tertulis dengan maksud untuk memperoleh informasi dari responden secara langsung. Kuesioner adalah penyelidikan mengenai suatu masalah dengan jalan mngedarkan formulir, daftar pertanyaan, diajukan secara tertulis pada responden untuk mendapatkan jawaban tertulis.

\subsection{Metode Pengumpulan Data}

Metode pengumpulan data dalam penelitian ini menggunakan data primer yaitu data yang diperoleh dari subjek dengan cara memberikan daftar pertanyaan kepada responden. Kemudian data tersebut di analisis dengan menggunakan skala pengukurn yang disebut 
JUMANIS - BAJA VOL 4 NO 1 Prodi Kewirausahaan Februari 2022

ISSN : 2686-0554

ESSN : 2686-5939

DOI : 10.47080

dengan skala likert. Skala likert digunakan untuk mengatur sikap, pendapat, dan persepsi seseorang atau sekelompok orang tentang fenomena sosial.

\subsection{Definisi Operasional Variabel}

Menurut Sugiyono (2018:39) variabel adalah suatu kualitas ( qualities ) dimana peneliti mempelajari dan menarik kesimpulan darinya. Variabel penelitian adalah suatu atribut atau sifat atau nilai dari orang, objek atau kegiatan yang mempunyai variasi tertentu yang ditetapkan oleh peneliti untuk dipelajari dan kemudian ditarik kesimpulannya (Sugiyono 2018:39).

\section{A. Variabel Independen}

Variabelin dependen (VariabelBebas) adalah variabel yang mempengaruhi atau yang menjadi sebab perubahannya atau timbulnya variable terikat (sugiyono 2018:39). Variael bebas dalam penelitian ini yaitu :Beban Kerja (X1), Keselematan Kerja (X2)

B. Variabel dependen

Variabel dependen (VariabelTerikat) adalah Variabel yang dipengaruhi atau yang menjadi akibat, karena adanya variable bebas (sugiyono 2018:39). Variabel terikat dalam penelitian ini yaitu :Produktivitas Kerja (Y)

\subsection{Metode Analisis Data}

Metode analisis data dalam penelitian ini menggunakan penelitian uji instrument (Uji Validitas dan Uji Reliabilitas), analisis data kuantitatif yang mliputi uji asumsi klasik (Uji Normalitas, Uji Multikoloniaritas, dan Uji Heterokedastisitas), uji hipotesis ( Uji T, Uji F dan Uji Determinasi Parsial dan Simultan ).

\section{Hasil Penelitian dan Pembahasan}

\subsection{Profil Perusahaan}

Pada tahun 1975 telah dibangun sebuah kawasan pelabuhan perikanan nusantara karangantu yang beralamat di Desa Banten Kec. Kasemen Kota Serang Banten. Dengan akses yang cukup stategis dalam sebuah tempat pelabuhan ini hanya berjarak $120 \mathrm{~km} / 2 \mathrm{jam}$ menuju ke pelabuhan tanjung priok dan $25 \mathrm{~km} / 30$ menit menuju peabuhan merak, hingga pelabuah ke bandara Soekarno Hatta hanya berjarak $(100 \mathrm{~km})$ dengan waktu tempuh sekitar 1,5 jam melalui jalan tol, kemudian pemasaran ikan, pembekalan dan perbaikan kapal, 
JUMANIS - BAJA VOL 4 NO 1 Prodi Kewirausahaan Februari 2022

ISSN : 2686-0554

ESSN : 2686-5939

DOI : 10.47080

fishing ground WPP-RI 712 (Laut Jawa), WPP-RI 572 (Samudera Hindia) dan WPP-RI 711 (Laut Natuna), dekat dengan wisata religi Banten Lama dan wisata bahari, pelabuhan ini juga sebagai penyangga PPSJ Nizam Zachman (Muara Baru), ditempuh dengan waktu sekitar 3 jam melalui laut, dengan memiliki transportasi darat dengan waktu 24 jam dan keberadaan pelabuhan berada di Ibu Kota Provinsi dan dekat Ibu Kota Negara.

\subsection{Uji Instrumen}

\section{A. Uji Validitas}

Uji validitas yang digunakan dalam penelitian ini adalah teknik korelasi product moment pearson. Dapat dikatakan valid apabila hasil uji didapat rhitung > rtabel. Dalam pengujian ini dilakukan dengan menggunakan data dari 60 responden. Diketahui $\mathrm{N}=60$ dan $a=5 \%$, maka rtabel $=0,254$. Validitasi dari item yang diuji adalah sebagai berikut :

Tabel 4.1

Hasil Validitas

\begin{tabular}{|r|r|r|c|}
\hline No & R Hitung & R Tabel & Keterangan \\
\hline 1 & 0,432 & 0,254 & VALID \\
\hline 2 & 0,721 & 0,254 & VALID \\
\hline 3 & 0,695 & 0,254 & VALID \\
\hline 4 & 0,717 & 0,254 & VALID \\
\hline 5 & 0,678 & 0,254 & VALID \\
\hline 6 & 0,679 & 0,254 & VALID \\
\hline 7 & 0,738 & 0,254 & VALID \\
\hline 8 & 0,727 & 0,254 & VALID \\
\hline 9 & 0,389 & 0,254 & VALID \\
\hline 10 & 0,715 & 0,254 & VALID \\
\hline 11 & 0,633 & 0,254 & VALID \\
\hline 12 & 0,613 & 0,254 & VALID \\
\hline 13 & 0,682 & 0,254 & VALID \\
\hline
\end{tabular}

Berdasarkan hasil pengelolaan data diketahui bahwa seluruh pertanyaan variabel Beban Kerja (X1), Keselamatan Kerja (X2), dan Produktivitas Kerja (Y) menunjukkan nilai tinggi, sehingga dapat digunakan sebagai bahan pengujian selanjutnya. 
JUMANIS - BAJA VOL 4 NO 1 Prodi Kewirausahaan Februari 2022

ISSN : 2686-0554

ESSN : 2686-5939

DOI : 10.47080

\section{B. Uji Reliabilitas}

Uji reliabilitas menunjukkan sejauh mana hasil atau pengukuran dapat dipercaya atau menunjukkan bahwa instrument yang digunakan memiliki konsisten dalam pengukuran.Pengujian realibilitas dilakukan dengan membandingkan nilai alpha dengan ketentuan nilai alpha minimal adalah 0,60. Artinya jika nilai perhitungan alpha lebih besar dari 0,60 maka dinyatakan reliabel.Adapun uji Reliabilitas pada tabel berikut:

Tabel 4.2

Hasil Reliabelitas

\begin{tabular}{|r|r|r|}
\hline \multicolumn{1}{|c|}{$\begin{array}{c}\text { Cronbach's } \\
\text { Alpha }\end{array}$} & $\begin{array}{c}\text { Cronbach's Alpha } \\
\text { Based on } \\
\text { Standardized } \\
\text { Items }\end{array}$ & N of Items \\
\hline, 915 &, 917 & 13 \\
\hline
\end{tabular}

Berdasarkan hasil data diatas menunjukkan reliabilitas dengan hasil alpha sebesar 0,915 lebih besar dari nilai minimal apha0,60. Maka kesimpulan dari perhitungan ini dinyatakan reliabel.

\subsection{Uji Asumsi Klasik}

\section{A. Uji Normalitas}

Uji normalitas bertujuan untuk menguji apakah dalam model regresi, variabel pengganggu atau residual memiliki distribusi normal. Normalitas dikatakan normal atau tidak, dilakukan dengan melihat nilai signifikansi pada tabel Kolmogorov-Smirnov. Jika nilai signifikansi lebih besar sama dengan 0,05 (sig > 0,5) berarti data berdistribusi normal. Adapun uji normalitas pada tabel berikut : 
JUMANIS - BAJA VOL 4 NO 1 Prodi Kewirausahaan Februari 2022

ISSN : 2686-0554

ESSN : 2686-5939

DOI : 10.47080

Tabel 4.3

Hasil Normalitas

\begin{tabular}{|ll|r|}
\hline & & Unstandardized Residual \\
\hline Normal Parameters ${ }^{\mathrm{a}, \mathrm{b}}$ & Mean & 60 \\
& Std. Deviation & $0 \mathrm{E}-7$ \\
& Absolute & 1,71933990 \\
Most Extreme Differences & Positive &, 111 \\
& Negative &, 111 \\
Kolmogorov-Smirnov Z & &,- 078 \\
Asymp. Sig. (2-tailed) & &, 857 \\
\hline
\end{tabular}

a. Test distribution is Normal.

b. Calculated from data.

\section{Gambar 4.1 \\ Gambar Normalitas}

Berdasarkan tabel 4.4 dapat dilihat dari nilai sig. Pada bagian Kolmogorov-Smirnov sebesar 0,455 > 0,05. Jadi variabel - variabel dalam penelitian ini terdistirbusi normal.

\section{B. Uji Multikoloniaritas}

Berdasarkan tabel IV. 5 dapat dilihat dari nilai sig. Pada bagian Kolmogorov-Smirnov sebesar 0,455 > 0,05. Jadi variabel - variabel dalam penelitian ini terdistirbusi normal. Pengujian dalam penelitian ini adalah dengan melihat nilai tolerance dan lawannya serta nilai Variance Inflation Faktor (VIF). Nilai batas yang umum dipakai untuk menunjukkan adanya multikolinieritas adalah nilai tolerance $>0,10$ atau sama dengan nilai VIF $<10$. Adapun uji multikolinieritas pada tabel dibawah ini :

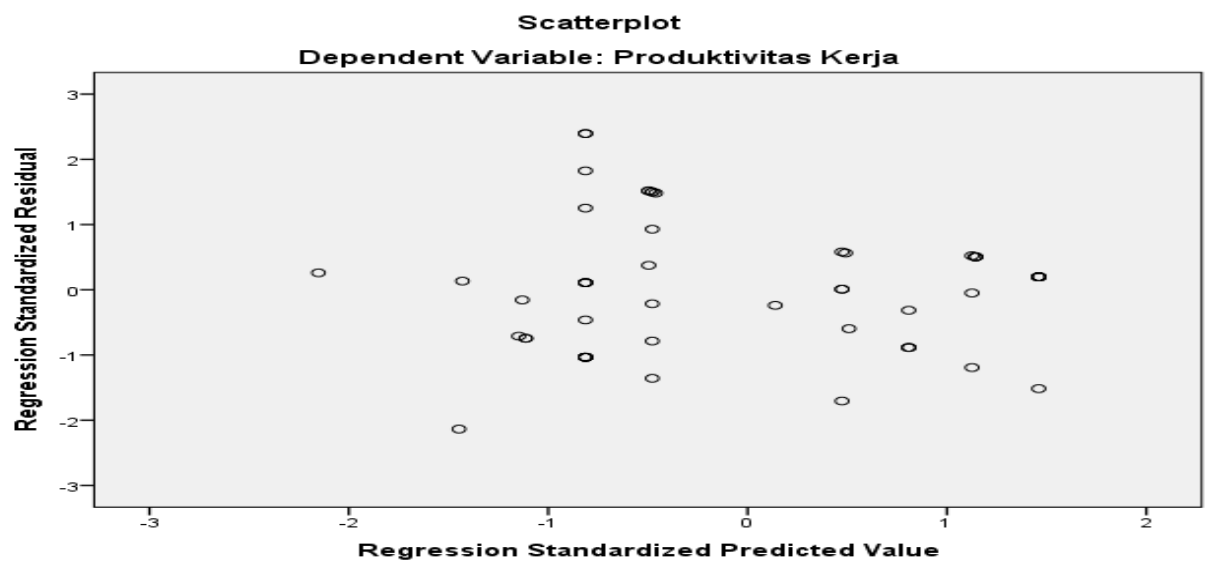




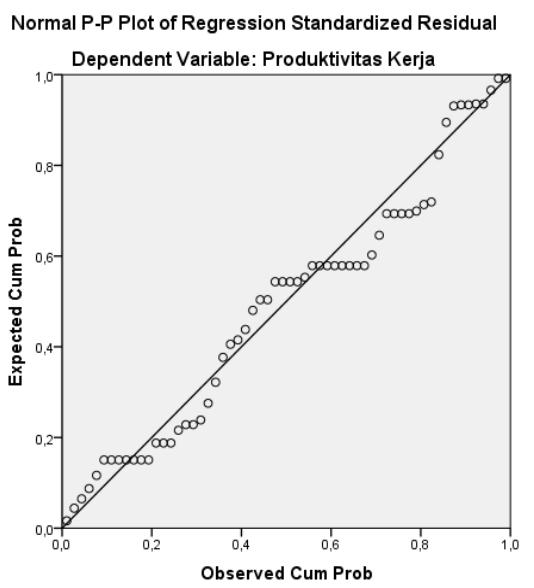

Tabel 4.4

Hasil Uji Multikolinieritas

\begin{tabular}{|l|l|l|}
\hline Variabel & Tolerance & VIF \\
\hline Beban Kerja (X1) &, 546 & 1,832 \\
\hline $\begin{array}{l}\text { Keselematan } \\
\text { Kerja (X2) }\end{array}$ &, 546 & 1,832 \\
\hline
\end{tabular}

Sumber: Data telah diolah

Dari hasil pengujian multikolinieritas yang dilakukan dapat disimpulkan bahwa nilai Variance Inflation Factor (VIF) kedua variabel yaitu, 1,832 < 10 sehingga tidak ada multikolinieritas antar variabel independen.

\section{Uji Heterokedastisitas}

Untuk uji heteroskedastisitas bertujuan untuk mengetahui adanya ketidaksamaan varians dari residual antara satu pengamatan dengan pengamatan yang lain.Heteroskedastsitas di uji dengan menggunakan uji koefisien korelasi Rank Sprearman yaitu mengkorelasikan antara absolut residual hasil regresi dengan semua variabel bebas. Bila signifkan hasil korelasi lebih kecil dari 0,05 maka persamaan regresi tersebut mengandung heteroskedastisitas dalam model penelitian dan berlaku untuk sebaliknya.Adapun uji heterokedastisitass pada tabel dibawah ini :

Tabel 4.5

Hasil Uji Heteroskedastisitas

Sumber: Data telah diolah

\begin{tabular}{|l|c|c|c|}
\hline $\begin{array}{c}\text { Variabel } \\
\text { Independen }\end{array}$ & $\mathrm{R}$ & Sig & Keterangan \\
\hline Beban Kerja &, 622 &, 000 & Homoskedastistas \\
\hline $\begin{array}{l}\text { Keselamatan } \\
\text { Kerja }\end{array}$ &, 658 &, 000 & Homoskedastistas \\
\hline
\end{tabular}

Gambar.4.2

Gambar Heterokedastisitas

Berdasarkan tabel dan gambar diatas menunjukkan bahwa variabel yang di uji tidak mengandung heteroskedastisitas, artinya tidak ada korelasi antara besarnya data dengan 
JUMANIS - BAJA VOL 4 NO 1 Prodi Kewirausahaan Februari 2022

ISSN : 2686-0554

ESSN : 2686-5939

DOI : 10.47080

residual sehingga data diperbesar tidak menyebabkan risedual (kesalahan) semakin besa juga.

\subsection{Uji Hipotesis}

\section{A. Uji T}

Analisis korelasi ini digunakan untuk mengetahui kekuatan hubungan antara korelasi kedua variabel di mana variabel lainnya dianggap berpengaruh dikendalikan atau dibuat tetap (sebagai variabel kontrol). Variabel yang diteliti adalah data rasio maka teknik yang digunakan adalah korelasi pearson proudct moment (Sugiyono, 2014:248)

Tabel 4.6 Hasil Uji T

\begin{tabular}{|c|c|c|}
\hline \multicolumn{3}{|c|}{ Coefficients $^{a}$} \\
\hline Model & $\mathrm{t}$ & Sig. \\
\hline (Constant) & 4,562 & ,000 \\
\hline 1 Beban Kerja & 2,562 & ,013 \\
\hline Keselamatan Kerja & 3,420 & ,001 \\
\hline
\end{tabular}

a. Dependent Variable: Produktivitas Kerja

Dari Tabel di atas variabel beban kerja menunjukkan nilai signifikansi untuk variabel Beban Kerja adalah $0,013<0,05$ dan hasil statistik uji t menunjukkan nilai thitung sebesar 2,562 dan tabel $(0,05 ; 2,58)=2,002$. Sedangkan variabel keselamatan kerja menunjukkannilai signifikansi untuk variabel Keselamatan Kerja adalah 0,001<0,05 dan hasil statistik uji t menunjukkan nilai thitungsebesar 3,420 dan ttabel 2,002.sehingga dapat disimpulkan bahwa beban kerja dan keselamatan kerja berpengaruh terhadap Produktivitas Kerja Pada Pegawai Pelabuhan Perikanan Nusantara Karangantu dapat diterima karena memiliki nilai signifikansi lebih kecil dari 0,05

\section{B. Analisi Linier Berganda dan Uji F}

Analisis linier berganda digunakan untk mengetahi terdapat lebih dari satu variable bebas yang akan diuji untuk mengetahui pengaruhnya terhadap variable terikat, maka proses analisis regresi yang dilakukan adalah dengan menggunakan analisis regresi berganda. Sedangkan Uji statistik F menunjukkan apakah variable bebas yang dimasukkan dalam 
JUMANIS - BAJA VOL 4 NO 1 Prodi Kewirausahaan Februari 2022

ISSN : 2686-0554

ESSN : 2686-5939

DOI : 10.47080

model regresi berganda mempunyai pengaruh secara serentak terhadap variable terikat. Imam Ghozali (2012:98)

Tabel 4. 7 Hasil regresi linier berganda dan Uji F

\begin{tabular}{|c|c|c|c|}
\hline Variabel & Koef & $\mathrm{t}$ hitung & sig \\
\hline Konstatnta & 10,437 & 4,562 &, 000 \\
\hline Beban Kerja (X1) &, 566 & 2,562 &, 013 \\
\hline Keselamatan Kerja (X2) &, 536 & 3,420 &, 001 \\
\hline F hitung & \multicolumn{2}{|c|}{27,546} & 0,000 \\
\hline
\end{tabular}

Sumber: Data telah diolah,

Berdasarkan persamaan tabel diatas, dapat disimpulkan bahwa Beban Kerja memberikan nilai koefisien 0,566, dan Keselamatan Kerja memberikan nilai koefisien 0,536 yang memiliki hubungan positif.

Hasil uji F pada Tabel 411 diperoleh Fhitung= 27,546 yang lebih besar dari Ftabel $(0,05 ; 2,58)=3,16$ dengan nilai probabilitas $=0,000$. Pada taraf signifikansi 5\% $(0,05)$, maka sig. sebesar $0,000<0,05$, sehingga dapat disimpulkan bahwa beban kerja dan keselamatan kerja secara simultan berpengaruh terhadap Produktivitas pada Pelabuhan Perikanan Nuantara Karangantu.

\section{Uji Determinasi $\mathbf{R}^{2}$}

Menurut Priyatno ( 2012 ) koefisien determinasi digunakan untuk mengetahui seberapa besar presentase sumbangan pengaruh variable independen secara bersaama sama terhadap variable dependen.

Tabel 4. 8 Hasil uji Koefisien Determinasi

\begin{tabular}{|l|c|r|r|r|}
\hline $\begin{array}{l}\text { Mod } \\
\text { el }\end{array}$ & $R$ & $\begin{array}{c}\text { R } \\
\text { Square }\end{array}$ & $\begin{array}{r}\text { Adjusted } \\
\text { R Square }\end{array}$ & $\begin{array}{c}\text { Std. Error } \\
\text { of the } \\
\text { Estimate }\end{array}$ \\
\hline 1 &, $701^{\text {a }}$ &, 491 &, 474 & 1,749 \\
\hline
\end{tabular}

a. Predictors: (Constant), Keselamatan Kerja,

Beban Kerja

b. Dependent Variable: Produktivitas Kerja

Sumber: Data sekunder telah diolah 
JUMANIS - BAJA VOL 4 NO 1 Prodi Kewirausahaan Februari 2022

ISSN : 2686-0554

ESSN : 2686-5939

DOI : 10.47080

Dari Koefisien determinasi dalam penelitian ini menggunakan nilai Rsquare. Berdasarkan hasil perhitungan uji determinasi yang tampak pada Tabel 4.8, besarnya koefisien determinasi atau Rsquare adalah 0,491. Hal ini berarti 49,1\% dapat dijelaskan oleh variabel beban kerja dan keselamatan kerja sedangkan sisanya $(100 \%-49,1 \%=50,9 \%)$ dijelaskan oleh variabel lain di luar penelitian ini.

\section{Uji Determinasi Parsial}

Koefisien determinasi parsial digunakan untuk mengetahui seberapa besar presentase pengaruh masing masing variable independen terhadap variabel dependen

1. Beban Kerja (X1)

KD Parsial $=$ Zero Order X1 x Beta X1

$$
\begin{aligned}
& =0,622 \times 0,328 \\
& =0,204 / 20 \%
\end{aligned}
$$

2. Keselamatan Kerja (X2)

KD Parsial $=$ Zero Order X2 $\times$ Beta X2

$$
\begin{aligned}
& =0,658 \times 0,437 \\
& =0,287 / 29 \%
\end{aligned}
$$

Berdasarkan hasil perhitungan diatas Keselamatan Kerja (X2) memiliki pengaruh yang paling besar terhadap Produktivitas Kerja sebesar 29\% dibandingkan dengan pengaruh Beban kerja terhadap Produktivitas Kerja sebesar $20 \%$.

\section{PENUTUP}

\subsection{Kesimpulan}

Setelah melakukan pembahasan pada BAB IV, maka dapat diperoleh kesimpulan sebagai berikut:

1. Variabel Beban Kerja berpengaruh terhadap Produktivitas Kerja Pelabuhan Perikanan Nusantara Karangantu Sesuai hipotesis penelitian ini.

Hal ini dibuktikan dengan hasil uji t statistic untuk variable Beban Kerja adalah 0,013 $<0,05$ dan hasil statistik uji t menunjukkan nilai thitung sebesar 2,562 dan tabel $(0,05 ; 2,58)=2,002$. Beban Kerja memiliki interprestasi Lemah dengan Koefisien 
JUMANIS - BAJA VOL 4 NO 1 Prodi Kewirausahaan Februari 2022

ISSN : 2686-0554

ESSN : 2686-5939

DOI : 10.47080

Determinasi Parsial sebesar 0,204 atau 20\%. Hal ini sesuai dengan yang pernah di teliti oleh Jurnal Encep Saefullah dan Hendri Kurniawan

2. Variabel Keselamatan Kerja berpengaruh terhadap Produktivitas Kerja Pelabuhan Perikanan Nusantara Karangantu Sesuai hipotesis penelitian ini.

Hal ini dibuktikan dengan hasil uji t statistic untuk variable Keselamatan Kerja adalah $0,001<0,05$ dan hasil statistik uji t menunjukkan nilai thitung sebesar 3,420 dan tabel 2,002. Keselamatan Kerja memiliki interprestasi Lemah dengan Koefisien Determinasi Parsial sebesar 0,287 atau 29\%. Hal ini sesuai dengan yang pernah di teliti oleh Jurnal Muhammad Busyairi dan Andri Saputra.

3. Variabel Beban Kerja dan Keselamatan Kerja berpengaruh terhadap Produktivitas Kerja Pelabuhan Perikanan Nusantara Karangantu Sesuai hipotesis penelitian ini.

Hal ini dibuktikan dengan hasil uji f statistic untuk variable Fhitung= 27,546 yang lebih besar dari Ftabel $(0,05 ; 2,58)=3,16$ dengan nilai probabilitas $=0,000$. Pada taraf signifikansi 5\% (0,05), maka sig. sebesar 0,000<0,05. Koefisien Determinasi Rsquare secara Simultan sebesar 0,491 atau 49,1\%

\subsection{Saran}

1. Bagi Pelabuhan

Berdasarkan hasil kuesioner beban kerja menyatakan baik akan tetapi harus ada yang diperbaiki terkait kondisi pekerjaan dan waktu bekerja yang sesuai dengan Standar Operasional Prosedur Pelabuhan dan tugas atau target dalam melaksanakan pekerjaan. Khususnya dalam pelaksanaan waktu bekerja yang sesuai dengan standar pekerjaan pegawai, sehingga bebankerja yang dimiliki pegawai bias berkurang dan pegawai dapat meningkatkan produktivitas kerja untuk pelabuhan.

Berdasarkan hasil kuesioner keselamatan kerja menyatakan baik akan tetapi harus ada yang diperbaiki terkait pemberian pemahaman dan pelatihan tentang keselamatan kerja, pemberian perlakuan adil terhadap semua Pegawai, menyediakan alat perlindungan standar kerja dalam ruangan maupun luar ruangan, pemberian tanda - tanda yang berbahaya dan mudah dipahami. Khususnya dalam perlakuan yang adil dan perlindungan terhadap pegawai, sehingga dengan keselamatan kerja yang tinggi, semakin tinggi keselamatan pegawai semakin tinggi pula produktivitas kerja pegawai untuk pelabuhan.

Dengan hasil penelitian ini, sebaiknya pelabuhan dapat lebih memperhatikan lagi dalam beban kerja dan keselamatan kerja. Karena dari hasil penelitian ini pelabuhan tersebut masih belum maksimal dalam mengatur beban kerja dan keselamatan kerja yang mana diketahui beban kerja dan keselamatan kerja pengaruh terhadap produktivitas kerja pelabuhan. Hal 
JUMANIS - BAJA VOL 4 NO 1 Prodi Kewirausahaan Februari 2022

ISSN : 2686-0554

ESSN : 2686-5939

DOI : 10.47080

tersebut dapat menurunkan produktivitas kerja sehingga hasil kerja yang didapat belum maksimal .

2. Bagi Peneliti Selanjutnya

Bagi peneliti selanjutnya, sebaiknya menambah Variabel baru yang dapat memberikan kontribusi terhadap Produktivitas Kerja. Sehingga memungkinkan hasilnya lebih baik dari penelitian ini dan diperoleh hasil yang lebih maksimal.

\section{Daftar Pustaka}

Ghozali, Imam.2012.Aplikasi Analisis Multivariate dengan Program IMB SPSS 20. Penerbit Universitas Diponegoro, Semarang

Nawawi, Hadari.2009.Manajemen Sumber Daya Manusia. Penerbit : Gadjah Mada Universit Press

Hasibuan, Melayu SP.2014. Menejemen Sumber Daya Manusia, edisi revisi, Cetakan keempatbelas, Jakarta, Penerbit : Bumi Aksara

Koesmowidjojo. Mar'ih.R.Suci .2017.Analisis Beban Kerja.Raih Asa Sukses

Mangkunegara,A. Prabu.2015.Manajemen Sumber Daya Manusia.Cetakan Keduabelas.Bandung:Unit Penerbit oleh PT Remaja Rosdakarya ..2015.Manajemen Sumber Daya Manusia.CetakanKeduabelas.Bandung:Unit Penerbit oleh PT Remaja Rosdakarya

Moenir, A.S. 2010. Manajemen Pelayanan Umum di Indonesia. Penerbit : Bumi Aksara

Priyatno, Duwi. 2012. Cara Kilat Belajar Analisis Data dengan SPSS 20. Penerbit : Andi Publisher

Suma'mur, PK.2009.keselamatan kerja dan pencegahan kecelakaan. Jakarta : CV. Haji Mas Agung

Sugiyono.2018.Metodologi Penelitian Kuantitatif, Kualitatif, dan R\&D. Cetakan ke 27.Bandung.Penerbit CV Alfabeta

Suparyadi.2015. Manajemen Sumber Daya Manusia: menciptakan Keunggulan Bersaing Berbasis Kompetensi SDM.Yogyakarta Penerbit : Andi.

Sutrisno, Edy.2016.Manajemen Sumber Daya Manusia. Cetakan ke Delapan.Penerbit : Kencana

Sinungan, Muchdarsyah. 2014. Produktivitas Apa dan Bagaimana. Penerbit : Bumi Aksara. 
JUMANIS - BAJA VOL 4 NO 1 Prodi Kewirausahaan Februari 2022

ISSN : 2686-0554

ESSN : 2686-5939

DOI : 10.47080

Soleman, A. (2011). Analisis Beban Kerja Ditinjau Dari Faktor Usia dengan Pendekatan Recommended Weiht Limit. ARIKA,5(2)

Yuniarsih, Tjuju.2009. Manajemen Sumber Daya Manusia. Bandung: CV. Alfabeta , Tjuju.2013. Manajemen Sumber Daya Manusia. Bandung: CV. Alfabeta

Apriani, D. Nurazi, R \& Praningrum.2013. Analisis Karakteristik Individu, Komitmen, Organisasi Beban Kerja dan Kinerja Pegawai Dinas Pendidikan Nasional Provinsi Bengkulu.The Manager Review Jurnal Ilmiah Manajemen, 15(1):113-130

Andri, Saputra.2014."Pengaruh Keselmatan Kerja Terhadap Produktivitas Kerja Karyawan Pada PT. Buran Nusa Respato Di Kecamatan Anggana Kabupaten Kukar".eJournal Pemerintahan 2014. 2 (3):3059-3069 ISSN 2338-3561

Encep, Saefullah. Listiawati. Asti, Nur Amalia.2017.'Pengaruh Beban Kerja dan Stress Kerja terhadap Produktivitas Kerja Karyawan”.AKADEMIKA.Vol.15 No. 2 Agustus 2017

Hendri, Kurniawan. Muh, Mukeri W. Azis, Fathoni.2016.'Pengaruh Riward, Punishment, Beban Kerja, dan Pelatihan Kerja Terhadap Produktivitas Kerja Karyawan (Studi Kasus Pada Karyawan PT Andalan Arthalestari Semarang)".Journal of Management.Vol. 2 No. 2 Maret 2016

Muhammad, Busyairi. La, Ode Ahmad S. T. Ayu, Oktaviani. 2014.”Pengaruh Keselamatan Kerja dan Kesehaatan Kerja terhadap Produktivitas Kerja Karyawan”.Jurnal Ilmiah Teknik Industri. Vol.13 No. 2, Des 2014

Afrizal, Firmanzah. Djambur, Hamid. Mochamad, Djudi.2017.'Pengaruh Keselamatan Kerja dan Kesehatan Kerja Terhadap (Studi Karyawan PT. PLN (Persero) Area Kediri Distribusi jawa Timur )".Jurnal Administrasi Bisnis (JAB). Vol. 42 No. 2 Januari 2017

Amalia, Syarah. Fakhri, Mahendra.2016."Pengaruh Motivasi Kerja Terhadap Kinerja Karyawan Pada PT. Gramedia Asri Media Cabang Emelard Bintaro". Jurnal Computech \& Bisnis. Vol. 10, No. 2. Desember 2016

Dewita, Ida Ayu. R. Setiawan, Putu. E. 2016. Pengaruh Ukuran Perusahaan, Umur Perusahaan, Profitabilitas, Leverage, dan Pertumbuhan Penjualan Terhadap Tax Avoidance. Vol.14 No.3 Maret 2016. Bali

Farda, Eka Septiana. Aniek Wahyuati.2016.”Pengaruh Rasio Keuangan Terhadapreturn Saham Pada Perusahaan".Jurnal Ilmu Dan Riset Manajemen : Volume 5, Nomor 1, Januari 2016 
JUMANIS - BAJA VOL 4 NO 1 Prodi Kewirausahaan Februari 2022

ISSN : 2686-0554

ESSN : 2686-5939

DOI : 10.47080

Guswanto, Beni. Gumilar, Iwang. Hamdani, Heman.2012."Analisis indeks kinerja pengelola dan indeks kepuasan pengguna dipelabuhan perikanan samudera nizam zachman Jakarta". Vol. 3, No.4 Desember 2012: 151-163

Irvianto, Laksmi S. Dwi. Veina, R. Eka.2015.”Analisis Pengaruh Stres Kerja, Beban Kerja dan Lingkungan Kerja Terhadap Turnover Intention Karyawan pada PT XL Axiata Tbk Jakarta”.Binus Business Review.Vol.6 No. 1 Mei 2015 117-126

Karima, Nur A. Indayati. Umar, Fauzan. 2017."Pengaruh Masa Kerja, Pelatihan dan Motivasi Terhadap Produktivitas Kerja Karyawan Pada PT. Bank Sulselbar Cabang utama Makassar".

Ningsih, Suhardi.2017.'Pengaruh Kejenuhan Kerja, Beban Kerja, dan Konflik Kerja Terhadap Motivasi Kerja Perawat RSUD DR. RM. Pratomo Bagan Siapiapi Kabupaten Rokan Hlir". JOM Fekon.Vol 4 No. 1 Februari 2017

Rachman, Bangkit. Noor.2018.”Analisis Faktor-faktor Keputusan Pembelian Smartphone Samsung pada Gerai Samsung Supermall Cilegon". Skripsi Cilegon

Slamet Nurmawanto, 2014. "Pengaruh Insentif Terhadap Produktifitas Kerja diKantor (Representatif Office) PT Asuransi Takaful Keluarga Cipulir”.Skripsi, Jakarta

Yuliana, Patrisia.2018.'Pengaruh Beban Kerja, Kelelahan Kerja dan Kesehatan dan Keselamatan Kerja (K3) Pada Karyawan PT. Kaltim Diamond Coal (KDC)".PSIKOBORNEO.Vol. 6 No. 1 2018: 183-198

Zulkarnaen, Wandy. Suarsa, Abin. Kusmana, Rachmat.2018.'Pengaruh Pelatihan Kerja dan Stress Kerja Terhadap Produktvitas Kerja Karyawan Bagian Produksi Departemen RPET PT. Namasindo PLAS Bandung Barat".Jurnal Ilmiah MEA(Manajemen, Ekonomi \& Akuntansi). Vol.2 No.3 Septembe-Desember2018

http://pipp.djpt.kkp.go.id/profil_pelabuhan/1309/informasi

\section{http://nasional.kontan.co.id}

http://poskotanews.com/2019/01/15/angka-kecelakaan-kerja-cenderung-meningkat-bpjsketenagakerjaan-bayar-santunan-rp12-triliun/ 